\title{
Analisis Efektivitas Biaya Penggunaan Metildopa Dibandingkan dengan Nifedipine Pada Pasien Preeklampsia Rawat Inap Di RSUD H. Abdul Manap Kota Jambi
}

\author{
Wiwit Wulan Safitri ${ }^{1}$, Rasmala Dewi ${ }^{1}$ dan Deny Sutrisno ${ }^{1}$ \\ ${ }^{1}$ Program Studi Farmasi, STIKES Harapan Ibu, Jambi, Indonesia, Jl. Tarmizi Kadir No. 71 Jambi 36132, (0741) 7552270 \\ Reception date of the manuscript: 23 November 2020 \\ Acceptance date of the manuscript: 27 April 2021 \\ Publication date: 31 Desember 2021
}

\begin{abstract}
Hypertension in pregnancy or preeclampsia was one of the main causes of morbidity and mortality in fetuses and pregnant women. Treatment for hypertension in pregnant women must be safe and appropriate, so the treatment of preeclampsia requires special attention to obtain effective therapy at a more rational cost. One methodology that can be used to conduct pharmacoeconomic research is a cost effectiveness analysis. This study aimed to determine the most effective use of drugs between methyldopa and nifedipine in terms of costs and benefits (outcomes) resulting in inpatients of preeclampsia hospitalized at H. Abdul Manap Hospital, Jambi City. This study was designed descriptively with retrospective data collection, by taking data from the medical records of inpatients at $\mathrm{H}$. Abdul Manap Hospital, Jambi City. The number of samples in this study were 67 patients. The results of the study can be seen from the ACER value. ACER is a value that expresses the amount of cost required for each improvement in treatment outcome. Of the 67 samples showed that the antihypertensive nifedipine had lower ACER values than methyldopa antihypertensives. The most effective use of antihypertensive drugs in reducing blood pressure in preeclampsia is nifedipine with an ACER value in 2016 of Rp. 6,948, in 2017 Rp. 7,035, and in 2018 Rp. 8,572 .
\end{abstract}

Keywords—cost effectiveness analysis, preeclampsia, methyldopa, nifedipine

\begin{abstract}
Abstrak - Penyakit hipertensi pada kehamilan atau preeklampsia merupakan salah satu penyebab utama morbiditas dan mortalitas pada janin dan ibu hamil. Pengobatan hipertensi pada wanita hamil harus aman dan tepat, sehingga pengobatan pada preeklampsia memerlukan perhatian khusus untuk mendapatkan terapi yang efektif dengan biaya yang lebih rasional. Salah satu metodologi yang digunakan untuk melakukan penelitian farmakoekonomi analah analisis efektivitas biaya. Penelitian ini bertujuan untuk mengetahui penggunaan obat yang paling efektif antara metildopa dengan nifedipine secara biaya dan manfaat (outcome) yang dihasilkan pada pasien preeclampsia rawat inap di RSUD H. Abdul Manap Kota Jambi. Penelitian ini dirancang secara deskriptif dengan pengambilan data secara retrospektif, dengan mengambil data dari rekam medik pasien rawat inap di RSUD H. Abdul Manap Kota Jambi. Jumlah sampel pada penelitian ini sebanyak 67 pasien. Hasil penelitian dapat dilihat dari nilai ACER. ACER adalah nilai yang menyatakan besaran biaya yang dibutuhkan untuk setiap peningkatan outcome pengobatan. Dari 67 sampel menunjukkan bahwa antihipertensi nifedipine memiliki nilai ACER lebih rendah dari antihipertensi metildopa. Penggunaan obat antihipertensi yang paling efektif dalam menurunkan darah pada preeklampsia adalah nifedipine dengan nilai ACER tahun 2016 Rp. 6.948, tahun 2017 Rp. 7.035, dan tahun 2018 Rp. 8.572.
\end{abstract}

Kata Kunci-analisis efektivitas biaya, preeklampsia, metildopa, nifedipine

\section{Pendahuluan}

Menurut Data dan Informasi Profil Kesehatan Indonesia, pada tahun 2018 angka kehamilan di Indonesia mencapai 5.291.143 jiwa. Pada tahun yang sama di provinsi Jambi terdapat 72.717 ibu hamil (Kemenkes RI, 2018). WHO memperkirakan sekitar $15 \%$ dari seluruh wanita hamil dapat berkembang menjadi komplikasi pada kehamilannya (Evayanti, 2015). Adapun resiko mortalitas pada ibu hamil adalah per-

Penulis koresponden: Wiwit Wulan Safitri, wulansafitri.wws@gmail.com darahan, tekanan darah tinggi (hipertensi), infeksi berat, anemia, dll (Nursal,dkk,. 2015).

Penyakit hipertensi dalam kehamilan atau preeklampsia merupakan faktor penyebab utama mortalitas ibu hamil (Evayanti, 2015). Berdasarkan catatan Survei Demografi dan Kesehatan Indonesia (SDKI) 2016, jumlah kematian ibu di provinsi Jambi sebanyak 87 per 100.000 kelahiran hidup. Menurut WHO, kasus meninggal pada ibu hamil atau bersalin sekitar 585.000 pertahun dan $58,1 \%$ diantaranya dikarenakan oleh preeklampsia dan eklampsia (Radjamuda Montolalu, 2014). Preeklampsia merupakan suatu sindrom spesifik yang muncul pada wanita hamil, umumnya terjadi pada usia 
kehamilan diatas 20 minggu serta ditandai adanya kenaikan tekanan darah dan proteinuria. (Setyarini Suprapti, 2016). Keadaan ini dapat menyebabkan morbiditas dan mortalitas pada janin dan ibu hamil (Kaimmudin, dkk,. 2018).

Pengobatan pada penderita hipertensi bertujuan mengontrol tekanan darah pasien sehingga tidak mengganggu fisiologis tubuh dan merusak fungsi organ yang lain (Ristyaningsih,dkk., 2018). Terapi utama pada hipertensi ibu hamil meliputi metildopa dan nifedipine, kedua obat ini berasal dari golongan yang berbeda. Nifedipine merupakan salah satu golongan calcium channel blocker sedangkan metildopa termasuk golongan agonis reseptor alfa (POGI, 2016). Berdasarkan survei awal, preeklampsia merupakan penyebab resiko tinggi pada ibu hamil dan janin di poli Kebidanan RSUD H. Abdul Manap Kota Jambi serta terjadi peningkatan kasus preeklampsia pada tahun 2018. Selain itu, ditemukan kasus preeklampsia pada berbagai usia ibu hamil. Terapi pada hipertensi ibu hamil harus aman dan tepat, sehingga efek yang diinginkan dapat tercapai. Obat antihipertensi akan terdistribusi ke dalam uterus selanjutnya masuk ke janin, sehingga pengobatan pada preeklampsia membutuhkan perhatian khusus untuk mendapatkan terapi yang efektif dengan biaya yang lebih rasional.

Berdasarkan hasil penelitian Hafizah Tri Larasati tahun 2018 penggunaan antihipertensi nifedipine merupakan penggunaan yang paling efektif secara biaya dan outcome pada pasien preeklampsia di RSUD KH Daud Arif Kuala Tungkal tahun 2017 dan 2018.

Analisis efektivitas biaya merupakan salah satu metodologi yang digunakan pada penelitian farmakoekonomi. Analisa ini merupakan salah satu langkah untuk membantu mengambil keputusan pemilihan obat yang efektif secara manfaat dan biaya serta dapat dengan mudah diukur dalam nilai moneter (rupiah) (Anjami Piter, 2019). Penelitian ini dapat dijadikan bukti ilmiah untuk membantu dalam menentukan pilihan alternatif terapi yang tersedia sehingga menjadi efisien dan ekonomis tanpa mengabaikan manfaat yang didapatkan.

\section{Metode}

Penelitian ini merupakan penelitian yang bersifat deskriptif yaitu dengan memberikan gambaran atau mendeskripsikan terhadap objek yang diteliti melalui data atau sampel yang terkumpul. Pengambilan data secara retrospektif yaitu pengambilan data berdasarkan pengamatan terhadap peristiwa yang telah terjadi, dengan tujuan untuk mencari faktor resiko yang berkaitan dengan penyebab. Data diambil dengan melihat data rekam medik pasien dan daftar biaya pasien preeklampsia rawat inap RSUD H. Abdul Manap Kota Jambi 2016, 2017, dan 2018. Penelitian ini dilaksanakan pada bulan Juni-Juli 2020 di ruang rekam medik, intalasi farmasi dan bagian administrasi keuangan RSUD H. Abdul Manap Kota Jambi dengan data periode 2016-2018.

a) Kriteria inklusi meliputi :

1. Pasien preeklampsia yang menggu-nakan BPJS kelas 3

2. Pasien preeklampsia yang menggunakan obat metildopa atau nifedipine

3. Pasien preeklampsia yang menjalani rawat inap di RSUD H. Abdul Manap Kota Jambi periode 2016-2018

4. Mempunyai data rekam medik yang lengkap dan data identitas pasien dapat terbaca dengan jelas meliputi nama pasien, no. rekam medik, nama obat, umur, lama pe- rawatan, tekanan darah awal, tekanan darah akhir, jumlah proteinuria awal dan akhir.

b) Kriteria ekslusi meliputi :

1. Pasien preeklampsia yang menggunakan antihipertensi kombinasi

2. Pasien preeklampsia yang dirujuk ke rumah sakit lain atau pulang atas permintaan sendiri.

3. Pasien preeklampsia yang mem- punyai penyakit penyerta

Pasien yang telah memenuhi kriteria inklusi dan eksklusi, dapat dijadikan sampel penelitian dengan melihat data-data medik pasien yang meliputi nama pasien, nomor rekam medik, nama obat, umur, lama perawatan, tekanan darah awal, tekanan darah akhir, jumlah proteinuria awal dan proteinuria akhir. Data ini dicatat dalam lembar pengambilan data sedangkan data untuk biaya didapat dari bagian administrasi keuangan. Pada tahap pengolahan dan analisa data, data yang ditulis di lembar kerja kemudian dianalisa dan diolah. Data yang dianalisa dan diolah meliputi :

1. Data Demografi Pasien Data demografi pasien dalam penelitian ini meliputi usia pasien preeklampsia, usia kehamilan pasien preeklampsia dan gambaran penggunaan obat.

2. Perhitungan Biaya Pertihungan biaya diambil dari seluruh biaya yang dikeluarkan oleh pasien selama menjalani perawatan dicatat kemudian dilakukan perhitungan keseluruhan biaya. Keseluruhan biaya tersebut di jumlahkan kemudian diperoleh biaya total pengobatan perpasien.

Efektivitas pengobatan dapat dilihat dari penurunan tekanan darah awal dan tekanan darah akhir pasien yang mencapai target terapi $(<140 / 90 \mathrm{mmHg})$ atau sebagai outcome klinis setelah menjalani terapi, kadar proteinuria $<300 \mathrm{mg}$ dalam 24 jam atau tes urin dipstick dengan hasil negatif.

$$
\% \text { Efektivitas }=\frac{\text { Rata-rata biaya }(\%)}{\text { Efektivitas Terapi }(\%)}
$$

Analisis efektivitas biaya dapat dihitung menggunakan rumus Avarege Cost Effectiveness Ratio (ACER), dihitung berdasarkan ratio biaya dan \% outcome klinisnya atau efektivitasnya (Andayani, 2013).

$$
A C E R=\frac{a}{b} \times 100 \%
$$

ICER dapat dihitung berdasarkan ratio antara selisih biaya dan \% outcome klinis dari kedua kelompok terapi. Dirumuskan sebagai berikut:

$$
I C E R=\frac{\text { Biaya } A(R p)-\text { Biaya } B(R p))}{\text { Efektivitas } A(\%)-\text { Efektivitas } B(\%)}
$$

\section{HASIL}

Pada penelitian yang telah dilakukan, diperoleh jumlah total populasi pasien yang dengan diagnosis preeklampsia di RSUD H. Abdul Manap Kota Jambi tahun 2016-2018 sebanyak 124 pasien. Pada tahun 2016, jumlah sampel pada pasien preeklampsia sebanyak 25 pasien. Pada tahun 2017, jumlah sampel pasien preeklampsia adalah 23 pasien, dan pada tahun 2018, jumlah sampel preeklampsia sebanyak 19 pasien. Sehingga jumlah sampel yang didapatkan berdasarkan kriteria inklusi sebanyak 67 pasien. Pasien preeklampsia yang mengalami preeklmapsia diantaranya menggunakan BPJS, Askes, SKTM, pasien umum, serta pasien yang memiliki penyakit bawaan, menggunakan obat kombinasi, 
JURNAL FARMASI UDAYANA I pISSN: 2301-7716; eISSN: 2622-4607 I VOL. 10, NO. 2, 2021

TABel 1: Distribusi Pasien Preeklampsia Berdasarkan Usia TAhun 2016-2018 (DePKes RI, 2009)

\begin{tabular}{clccc}
\hline \multirow{2}{*}{ No } & \multirow{2}{*}{ Kategori Usia (tahun) } & Tahun 2016 & Tahun 2017 & Tahun 2018 \\
\cline { 3 - 5 } & & $\mathrm{n}$ & $\mathrm{n}$ & $\mathrm{n}$ \\
\hline 1 & Remaja akhir (17-25 th) & 3 & 8 & 5 \\
\hline 2 & Dewasa awal (26-35 th) & 18 & 10 & 10 \\
\hline 3 & Dewasa akhir (36-45 th) & 4 & 4 & 4 \\
\hline 4 & Lansia awal (46-55 th) & 0 & 1 & 0 \\
\hline & Total & 25 & 23 & 19 \\
\hline
\end{tabular}

Tabel 2: Distribusi Pasien Preeklampsia Berdasarkan Usia Kehamilan TAhun 2016- 2018 (DepKes RI, 2006)

\begin{tabular}{ccccc}
\hline \multirow{2}{*}{ No } & \multirow{2}{*}{ Usia kehamilan } & Tahun 2016 & Tahun 2017 & Tahun 2018 \\
\cline { 3 - 5 } & & $\mathrm{n}$ & $\mathrm{n}$ & $\mathrm{n}$ \\
\hline 1 & Trimester I (0-12 minggu) & - & - & - \\
\hline 2 & Trimester II (13-28 minggu) & 4 & 3 & 1 \\
\hline 3 & Trimester III (29-42 minggu) & 21 & 20 & 18 \\
\hline & Total & 25 & 23 & 19 \\
\hline
\end{tabular}

Tabel 3: Persentase Penggunaan Obat Pada Pasien Preeklampsia Tahun 2016-2018

\begin{tabular}{cccccccc}
\hline \multirow{2}{*}{ No } & \multirow{2}{*}{ Obat } & \multicolumn{2}{c}{ Tahun 2016 } & \multicolumn{2}{c}{ Tahun 2017 } & \multicolumn{2}{c}{ Tahun 2018 } \\
\cline { 3 - 8 } & & $\mathrm{n}$ & $\%$ & $\mathrm{n}$ & $\%$ & $\mathrm{n}$ & $\%$ \\
\hline 1 & Nifedipine $10 \mathrm{mg}$ & 11 & 44 & 9 & 39.13 & 7 & 36.84 \\
\hline 2 & Metildopa 250 mg & 14 & 56 & 14 & 60.87 & 12 & 63.16 \\
\hline & Total & 25 & 100 & 23 & 100 & 19 & 100 \\
\hline
\end{tabular}

data pasien tidak lengkap dan pasien yang dirujuk ke rumah sakit lain. Pengelompokan distribusi berdasarkan usia bertujuan untuk mengetahui pada rentan usia terjadinya kasus preeklampsia terbanyak. Total pasien dari tahun 2016-2018 adalah 67 orang dengan usia yang berbeda-beda. Subjek penelitian usia terendah adalah 20 tahun dan usia tertinggi adalah 46 tahun. Tabel distribusi pasien preeklampsia berda- sarkan usia terdapat pada tabel 1. Berdasarkan pengelompokan usia kehamilan tahun 2016-2018, didapatkan hasil bahwa usia terbanyak terjadinya preeklampsia pada trimester III atau usia kehamilan 29-42 minggu. Pada tahun 2016, kehamilan usia 29-42 minggu sebanyak 21 orang, tahun 2017 berjumlah 20 orang dan tahun 2018 sebanyak 18 orang. Tabel distribusi pasien preeklampsia berdasarkan usia kehamilan dapat dilihat pada tabel 2. Berdasarkan tabel 3 Penggunaan obat antihipertensi terbanyak pada pasien preeklampsia tahun 2016-2018 adalah metildopa $250 \mathrm{mg}$, dengan persentase tertinggi pada tahun 2018 sebesar 63,16Pada tabel 4 Menunjukkan pada tahun 2016-2018 biaya total rata-rata yang paling besar dikeluarkan pasien preeklampsia yaitu pasien yang mendapat terapi metildopa $250 \mathrm{mg}$ dengan biaya terbesar yang dikeluarkan pasien pada tahun 2018 yaitu Rp. 809.376. Pada tahun 2018-2018 secara berurut nifedipine memiliki efektivitas pengobatan yang lebih tinggi dibandingkan dengan metildopa. Efektivitas nifedipine tertinggi tahun 2017 sebesar $77,78 \%$ dapat dilihat pada Tabel 5. Pada tahun 2016-2018 secara berturut nilai ACER terendah ditujukkan oleh obat nifedipine, sedangkan nilai ACER tertinggi ditujukkan oleh metildopa dapat dilihat pada Tabel 6 . Semakin rendah nilai ACER maka semakin efektif obat tersebut. Pada Tabel 6 menunjukkan biaya pengobatan rendah dengan efektivitas tinggi, sehingga tidak perlu dilakukan perhitungan ICER. Berdasarkan syarat kelompok intervensi alternatif ini masuk di kuadran II (dominan).

\section{Pembahasan}

Usia merupakan bagian dari status reproduksi yang penting. Usia dapat mempengaruhi status kesehatan seseorang dikarenakan adanya keterkaitan antara peningkatan dan penurunan fungsi tubuh. Pada usia 30-35 tahun atau lebih, ibu hamil memiliki resiko tinggi preeklampsia. Usia ibu hamil yang terlalu tua dapat menyebabkan gangguan fungsi organ karena proses menurunnya efisiensi. Proses menurunnya efisiensi atau degenerasi organ reproduksi dapat berdampak langsung pada saat proses bersalin (Lombo, dkk. 2017). Berdasarkan penelitian yang telah dilakukan, menunjukkan jumlah terjadinya preeklampsia lebih didominasi pada usia masa dewasa awal (26-35 tahun), hal ini sesuai dengan penelitian yang dilakukan oleh Chambali, dkk. yaitu usia sampel paling banyak berusia 26-35 tahun sebanyak 18 pasien dengan persentase sebesar 46,77Pada umumnya muncul tanda atau gejala-gejala preeklampsia dimulai pada trimester II, tetapi gangguan dapat dideteksi pada awal trimester III. Pada usia kehamilan 29-42 minggu (trimester III) lebih banyak mengalami preeklampsia karena pada usia tersebut dapat terjadi hipertensi sebagai reaksi meningkatnya metabolisme organ tubuh ibu, yakni plasenta mulai aktif dalam mengalirkan nutrisi pada janin. Semakin tua usia kehamilan, maka semakin tinggi frekuensi terjadinya preeklampsia (Chambali, dkk. 2019). Berdasarkan hasil penelitian, didapatkan hasil bahwa usia kehamilan terbanyak terjadinya preeklampsia pada usia kehamilan trimester III.

Nifedipine adalah salah satu obat antihipertensi golongan calcium channel blocker (CCB). Mekanisme kerja nifedipine yaitu merelaksasi jantung dan otot polos dengan cara menghambat influx kalsium sepanjang membran sel sehing- 
Tabel 4: Jumlah Biaya Total Rata-Rata Pada Pasien Preeklampsia Tahun 2016-2018

\begin{tabular}{ccccccccc}
\hline \multirow{2}{*}{ Tahun } & Obat & $\begin{array}{c}\text { Biaya } \\
\text { Obat } \\
\text { (Rp.) }\end{array}$ & $\begin{array}{c}\text { Biaya } \\
\text { Rawat Inap } \\
(\text { Rp. })\end{array}$ & $\begin{array}{c}\text { Biaya } \\
\text { Visite Dokter } \\
(\text { Rp. })\end{array}$ & $\begin{array}{c}\text { Biaya } \\
\text { Askeb } \\
(\text { Rp. })\end{array}$ & $\begin{array}{c}\text { Biaya } \\
\text { Tindakan } \\
(\text { Rp. })\end{array}$ & $\begin{array}{c}\text { Biaya } \\
\text { Laboratorium (Rp.) } \\
(\text { Rp. })\end{array}$ & $\begin{array}{c}\text { Biaya } \\
\text { Total Rata-Rata } \\
(\text { Rp. })\end{array}$ \\
\hline \multirow{2}{*}{2016} & Nifedipine 10 mg & 280 & 203.636 & 70.000 & 38.182 & 91.691 & 101.545 & 505.334 \\
\cline { 2 - 10 } & Metildopa $250 \mathrm{mg}$ & 9.575 & 257.143 & 86.964 & 48.214 & 113.936 & 155.743 & 671.575 \\
\hline \multirow{2}{*}{2017} & Nifedipine $10 \mathrm{mg}$ & 305 & 222.222 & 76.389 & 41.667 & 108.733 & 97.867 & 547.183 \\
\cline { 2 - 10 } & Metildopa $250 \mathrm{mg}$ & 9.788 & 262.857 & 90.357 & 49.286 & 134.357 & 119.500 & 666.145 \\
\hline \multirow{2}{*}{2018} & Nifedipine 10 mg & 298 & 217.143 & 74.643 & 40.714 & 132.486 & 146.986 & 612.270 \\
\cline { 2 - 9 } & Metildopa 250 mg & 11.668 & 313.333 & 107.708 & 58.750 & 142.842 & 175.075 & 809.376 \\
\hline
\end{tabular}

Tabel 5: Jumlah Biaya Total Rata-Rata Pada Pasien Preeklampsia Tahun 2016-2018

\begin{tabular}{|c|c|c|c|c|c|}
\hline No. & Obat & Tahun & $\begin{array}{l}\text { Jumlah Pasien } \\
\text { (Orang) }\end{array}$ & $\begin{array}{c}\text { Jumlah Pasien } \\
\text { Mencapai Target (Orang) }\end{array}$ & $\begin{array}{c}\text { Persentase Efektivitas } \\
\text { Pengobatan }(\%)\end{array}$ \\
\hline \multirow{3}{*}{1.} & \multirow{3}{*}{ Nifedipine $10 \mathrm{mg}$} & 2016 & 11 & 8 & 72,73 \\
\hline & & 2017 & 9 & 7 & 77,78 \\
\hline & & 2018 & 7 & 5 & 71,43 \\
\hline \multirow{3}{*}{2.} & \multirow{3}{*}{ Metildopa $250 \mathrm{mg}$} & 2016 & 14 & 9 & 64,28 \\
\hline & & 2017 & 14 & 10 & 71,43 \\
\hline & & 2018 & 12 & 8 & 66,67 \\
\hline
\end{tabular}

Tabel 6: Perhitungan Nilai ACER Pada Pasien Preeklampsia Tahun 2016-2018

\begin{tabular}{|c|c|c|c|c|}
\hline Obat & Tahun & Biaya Total & Efektivitas (\%) & ACER \\
\hline \multirow{3}{*}{ Nifedipine $10 \mathrm{mg}$} & 2016 & Rp. 505.334 & $72,73 \%$ & Rp. 6.948 \\
\hline & 2017 & Rp. 547.183 & $77,78 \%$ & Rp. 7.035 \\
\hline & 2018 & Rp. 612.270 & $71,43 \%$ & Rp. 8.572 \\
\hline \multirow{3}{*}{ Metildopa $250 \mathrm{mg}$} & 2016 & Rp. 671.575 & $64,28 \%$ & Rp. 10.448 \\
\hline & 2017 & Rp. 666.145 & $71,43 \%$ & Rp. 9.326 \\
\hline & 2018 & Rp. 809.376 & $66,67 \%$ & Rp. 12.140 \\
\hline
\end{tabular}

ga menghambat masuknya kalsium pada ekstraseluler ke dalam sel. Penghambatan masuknya kalsium menyebabkan kontraksi otot pembuluh darah menjadi menurun, sehingga menyebabkan vasodilatasi. (Dipiro C.V, 2015).

Metildopa merupakan obat antihipertensi golongan agonis alfa-2 sentral. Penggunaan metildopa dapat menurunkan tekanan darah dengan cara merangsang alfa-2 adrenergik di otak. Perangsangan ini menyebabkan turunya aliran simpatetik dari pusat vasomotor di otak dan meningkatkan tonus vegal. Penggunaan metildopa jangka panjang sebaiknya dikombinasikan dengan diuretik guna mencegah timbulnya efek yang tidak dinginkan, kecuali pada kehamilan (Indhayani, 2018).

Terapi yang diberikan pada pasien preeklampsia umumnya bervariasi tergantung bagaimana kondisi tubuh pasien. Perbedaan kondisi tubuh pasien mengakibatkan biaya medis yang dikeluarkan pasien juga bervariasi, tergantung dari biaya obat, biaya rawat inap, biaya visite dokter, biaya askeb, biaya cek laboratorium dan biaya tindakan. Berdasarkan hasil penelitian, pada tahun 2016-2018 biaya rawat inap pasien preeklampsia merupakan biaya medik terbesar dibandingkan dengan biaya medik lainnya, dikarenakan penurunan tekanan darah dan jumlah proteinuria mempengaruhi lama rawat pasien. Hasil penelitian ini sesuai dengan penelitian yang dilakukan Musdalipah, melaporkan bahwa biaya rawat inap merupakan biaya medik terbesar selama perawatan.

Analisis efektifitas biaya meru- pakan analisis yang membandingkan antara efektifitas terapi dengan biaya yang dike- luarkan (Baroroh Sari, 2017). Hasil dari analisis efektivitas biaya umumnya digambarkan dalam rasio, baik dengan ACER atau sebagai ICER (Andayani, 2013). Nilai ACER didapatkan dari perbandingan antara biaya total pengobatan rata-rata perbulan dibagi dengan efektivitas terapi pasien. Berdasarkan perhitungan nilai ACER antara obat nifedipine dan metildopa pada tabel 6 , yang dianggap paling cost effective adalah nifedipine karena nifedipine memiliki nilai ACER yang lebih kecil dibandingkan dengan metildopa. Hal ini dipengaruhi oleh biaya terapi nifedipine yang lebih murah dengan penurunan tekanan darah yang besar, dibandingkan dengan penggunaan metildopa yang biaya terapinya lebih mahal tetapi penurunan tekanan darahnya rendah.

Nilai ICER diperoleh dari perbandingan selisih biaya total pengobatan rata-rata perbulan dibagi dengan \% outcome klinis pada semua kelompok terapi (Wijayanti, dkk. 2016). Nilai ICER menunjukkan besarnya biaya tambahan yang diperlukan untuk memperoleh atau mencapai peningkatan satu unit outcome relatif terhadap pembandingnya atau untuk setiap unit perbaikan kesehatan (Andayani, 2013).

Pada penelitian ini didapatkan hasil bahwa nifedipine dengan biaya rendah efektivitas tinggi dan metildopa dengan biaya tinggi efektivitas rendah sehingga tidak perlu perhitungan ICER serta intervensi alternatif ini masuk di kuadran II (dominan) dan menjadi pilihan utama. 


\section{KESIMPULAN}

Berdasarkan hasil penelitian, dapat disimpulkan bahwa ditinjau dari efektivitas terapi dan biaya pasien preeklampsia, penggunaan antihiper- tensi nifedipine lebih efektif (cost effective) dari penggunaan antihipertensi metildopa pada tahun 2016-2018 di RSUD H. Abdul Manap Kota Jambi. Dilihat dari nilai ACER pada tahun 2016-2018 secara berurut nifedipine memiliki nilai ACER lebih rendah dari metildopa. Nilai ICER tidak perlu dihitung karena hasil penelitian ini menunjukkan hasil penggunaan antihipertensi nifedipine biaya rendah efektivitas tinggi dan metildopa dengan biaya tinggi efektivitas rendah. serta intervensi alternatif ini masuk di kuadran II (dominan).

\section{UCAPAN TERIMA KASIH}

Penulis mengucapkan terimakasih kepada RSUD H. Abdul Manap Kota Jambi atas kerja sama nya dalam penelitian ini.

\section{Daftar Pustaka}

Andayani, Tri Murti. (2013). Farmakoekonomi Prinsip Dan Metodologi. Jakarta: Bursa Ilmu. Anis Ristyaningsih, Nanang Munif Yasin Fivy Kurniawati. (2018). Studi Eksplorasi Penatalaksanaan Hipertensi pada Wanita Hamil. Jurnal Managemen dan Pelayanan Farmasi. Vol.8. No.4. 189 - 199.

Chambali, Miftachul Ainin, dkk. (2019). Analisis Efektivitas Biaya Penggunaan Antihipertensi Pada Pasian Preeklampsia Di RSUD Abdul Wahab Sjahranie periode 2018. Mulawarman Pharmaceutical Conferens.

Didien Ika Setyarini Suprapti. (2016). Asuhan Kebidanan Kegawat daruratan Maternal Neonatal. Jakarta : Kementrian kesehatan Republik Indonesia.

Dien Gusta Anggraini Nursal, Pratiwi Tamela Fitrayeni. (2015). Faktor Risiko Kejadian Preeklampsia Pada Ibu Hamil Di RSUP Dr. M. Djamil Padang Tahun 2014. Jurnal Kesehatan Masyarakat Andalas. Vol.10. No.1. 38-4.

Dipiro C.V. (2015). Pharmacorherapy Handbook (Ninth Edit). Inggris: McGraw-Hill Education Copmanies.

Faridah Baroroh Andriana Sari. (2017). Analisis Efektivitas Biaya Pengobatan Kombinasi Candesartan-Amlodipin Dibanding kan Dengan Kombinasi CandesartanDiltiazem Pada Pasien Hipertensi Rawat Jalan. Jurnal Pharmacy. Vol.14. No.2.

Giovanna E Lombo, Freddy W. Wagey Linda S. Mamengko. (2017). Karakteristik Ibu Hamil Dengan Preeklampsia Di Rsup Prof Dr. R. D. Kandou Manado. Jurnal Kedokteran Klinik (JKK). Vol. 1. No 3. 9-15.

Indhayani, Lidya. (2018). Studi penggunaan obat antihipertensi pada wanita hamil yang didiagnosis hipertensi di rumah sakit PMI Kota Bogor. Indonesian Journal Of Pharmaceutical Science and Technology. Vol. 7. No. 117.

Kemenkes RI. (2018). Data Dan Informasi Profil Kesehatan Indonesia. Jakarta: Kementerian Kesehatan Republik Indonesia.

Liawati Kaimmudin, Damayanti Pangemanan Hendro Bidjuni. (2018). Hubungan Usia Ibu Saat Hamil Dengan Kejadian Hipertensi Di Rsu Gmim Pancaran Kasih. EJournal Keperawatan (E-Kp).Vol.1. No.6. 1-5.
Nelawati Radjamuda Agnes Montolalu. (2014). FaktorFaktor Risiko Yang Berhubungan Dengan Kejadian Hipertensi Pada Ibu Hamil Di Poli Klinik Obs-Gin Rumah Sakit Jiwa Prof. Dr. V. L. Ratumbuysang Kota Manado. Jurnal Ilmiah Bidan. Vol.2. No.1. 33-40.

POGI. (2016) . Pedoman Nasional Pelayanan Kedokteran Diagnosis Dan Tata Laksana Pre-Eklamsia. Jakarta: Perkumpulan Obstetri dan Ginekologi Indonesia Himpunan Kedokteran Feto Maternal.

Widiana Anjami Piter. (2019). Analisis Efektivitas Biaya Penggunaan Obat Antihipertensi Pada Pasien Preeklampsia Di Rumah Sakit Islam Jakarta Tahun 20172018. Social Clinical Pharmacy Indonesia Journal. Vol 4. No.2. 19-23.

Yulistiana Evayanti. (2015). Hubungan Pengetahuan Ibu Dan Dukungan Suami Pada Ibu Hamil Terhadap Keteraturan Kunjungan Antenatal Care (Anc) Di Puskesmas Wates Lampung Tengah Tahun 2014. Jurnal Kebidanan. Vol. 1. No 2. $81-90$. 